\begin{tabular}{|l|l|l||}
\hline \multicolumn{2}{|c|}{ PublisherInfo } \\
\hline \hline PublisherName & $:$ & BioMed Central \\
\hline \hline PublisherLocation & $:$ & London \\
\hline \hline PublisherImprintName & $:$ & BioMed Central \\
\hline \hline
\end{tabular}

\title{
E. coli: the computer
}

\begin{tabular}{|l|l|l||}
\hline \multicolumn{2}{|c|}{ ArticleInfo } \\
\hline \hline ArticleID & $:$ & 3682 \\
\hline \hline ArticleDOI & $:$ & $10.1186 /$ gb-spotlight-20000509-03 \\
\hline \hline ArticleCitationID & $:$ & spotlight-20000509-03 \\
\hline \hline ArticleSequenceNumber & $:$ & 119 \\
\hline \hline ArticleCategory & $:$ & Research news \\
\hline \hline ArticleFirstPage & $:$ & 1 \\
\hline \hline ArticleLastPage & $:$ & 2 \\
\hline \hline & & RegistrationDate : 2000-05-09 \\
ArticleHistory & $:$ & OnlineDate \\
\hline \hline ArticleCopyright & $:$ & BioMed Central Ltd2000-05-09 \\
\hline \hline ArticleGrants & $:$ & \\
\hline \hline ArticleContext & $:$ & 130591111 \\
\hline \hline
\end{tabular}




\section{William Wells}

Email: wells@biotext.com

Edwards and Palsson get us ready for the day when all of biology will be intermediary metabolism by generating a computer model of Escherichia coli's metabolic genotype. In the May 9 Proceedings of the National Academy of Sciences they find that a network containing 436 metabolites and 720 reactions can correctly predict the qualitative growth potential of $86 \%$ of the mutant strains examined (Proc. Natl. Acad. Sci. USA 2000, 97:5528-5533). Edwards and Palsson spurn the use of exact kinetic parameters (which are available only for some reactions) in favor of some absolute constraints (reversibility of reactions, availability of energy sources) and optimization of the flux of metabolites through the network. This strategy is based on evidence that $E$. coli does, at least in some growth conditions, come close to a theoretically optimal growth state. The emergent propertiesof the network should allow researchers to choose the most informative knockout and growth experiments to explore how metabolism works.

\section{References}

1. PNAS online journal, [http://www.pnas.org/]

2. Complexity in biological signaling systems. 